\title{
Influence of the geometrical researches of ruled surfaces on design of unique structures
}

\author{
Iraida A. Mamieva \\ Peoples' Friendship University of Russia (RUDN University), 6 Miklukho-Maklaya St., Moscow, 117198, Russian Federation \\ mamieva-ia@rudn.ru
}

Article history:

Received: May 22, 2019

Revised: July 13, 2019

Accepted: July 27, 2019

For citation

Mamieva I.A. (2019). Influence of the geometrical researches of ruled surfaces on design of unique structures. Structural Mechanics of Engineering Constructions and Buildings, 15(4), 299-307. http://dx.doi.org/ 10.22363/1815-5235-2019-15-4-299-307
Abstract

Aims of research. Due to the growing interest in the design, calculation and application of architectural structures and structures in the form of a variety of smooth and composite surfaces, it is interesting to illustrate the use of analytical surfaces, i.e. surfaces that can be defined by vector, parametric or explicit equations, in parametric architecture. Methods. Parametric design unlike other styles has a relationship with mathematics. This article continues the author's series of works devoted to the application of analytical surfaces in architecture and engineering structures, the study of the influence of studies on the geometric of ruled surfaces on the creation of unique projects of large-span shell structures and buildings. The article provides a list of known analytical surfaces, and each surface is illustrated by a photo of only one real structure, outlined on this surface. Results. It turned out that only degenerate unfolding surfaces described in the scientific literature found application in the world. For those who are interested in the mathematical side of the design of analytical surfaces, their computer modeling, or more detailed information about the real structures in the form of the surfaces under consideration is a bibliography of 20 items.

Keywords: ruled surface; zero Gaussian curvature surfaces; parametric architecture; surface geometry; forming surfaces; surface classification; shell structure; large-span shell structures

\section{Introduction}

Nowadays there are known more than 600 analytical surfaces set by the explicit, implicit, or parametrical equations [1] that are grouped in 38 classes. There are several options of classifications of analytical surfaces; the fullest of them is presented in a work [2]. In some works, for example in [3-5], attempts to find out the most popular analytical surfaces among architects which were used for design of public, residential, and industrial buildings were made. The present manuscript continues the researches begun by the author in a work [6] in which the known thin-walled shell erections realized in practice or erections in design

Iraida A. Mamieva, Assistant of the Department of Civil Engineering.

(C) Mamieva I.A., 2019 (c) () This work is licensed under a Creative Commons Attribution 4.0 https://creativecommons.org/licenses/by/4.0/ of which the most prominent architects took part, or the structurers having the most optimum technicaland-economic parameters, or the structures noted by prizes and taking high places in various ratings of professional associations and magazines are presented. In this paper, only structures and erection having the form of ruled surfaces would be considered. Every analytical ruled surface is illustrated with one erection outlined on the corresponding surface.

\section{Ruled surfaces}

A surface formed by continuous movement of a straight line is called a ruled surface. Ruled surfaces are divided into surfaces of zero and negative Gaussian curvature. Zero Gaussian curvature surfaces are tangential developable surfaces with an edge of regression [7] and degenerated developable surfaces i.e. conical, cylindrical surfaces and the plane. 
A vector equation of a ruled surface can be written in the following form:

$$
r=r(u, v)=a(v)+u b(v),
$$

where $a(v)$ is the radius-vector of a directrix curve; $b(v)$ is the directrix vector of a rectilinear generatrix.

\section{Tangential developable surfaces (torse surfaces)}

Those who want to use analytical method of analysis may apply the equation of a tangential developable surface in the vector form:

$$
r=r(u, v)=a(v)+u l(v),
$$

where $a(v)$ is the radius-vector of a cuspidal edge,

$$
a(v)=x(v) i+y(v) j+z(v) l ;
$$

$x(v), y(v), z(v)$ are the parametric coordinates of the cuspidal edge; $l(v)$ is a unit tangent vector, given at every point of the cuspidal edge by

$$
l(v)=a(v)^{\prime} /\left|a(v)^{\prime}\right| .
$$

In the encyclopedia [1], 37 torse surfaces of various types are considered, but only architect Jess Maertterer designed a covering from the torse fragments (Figure 1) made by parabolic bending of metal strips. Now only the architect F.O. Gehry designs structures of this type [8]. All other offers on the application of nondegenerate torse surfaces in construction are presented in the form of sketches, descriptions, and schemes [9-11].

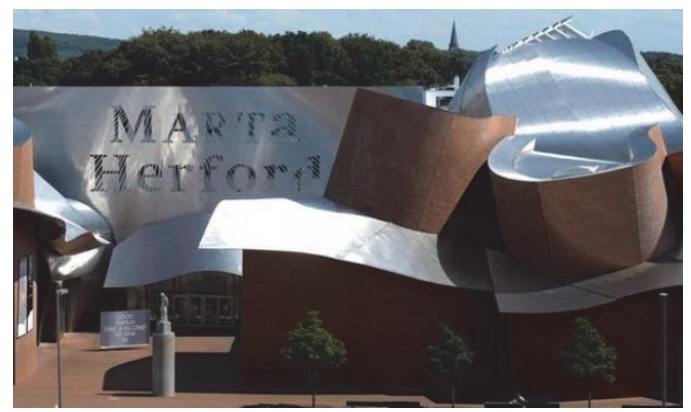

Figure 1. The MARTa museum in Herford, Germany.

The most part of roof covering is a developable surface. Geometric modelling of the roof was fulfilled by Jess Maertterer. The museum was recognized as the best museum of Germany in 2014

\section{Conical surfaces}

These surfaces are among the most widely used surfaces in architecture [12] and in machine-building structures. The scientific-and-technical literature describes 20 conical surfaces. In these developable surfaces, the edge of regression degenerates into a point that is the vertex of the cone. A conical surface can be described parametrically as

$$
S(t, u)=v+u q(t),
$$

where $v$ is the radius-vector of a vertex; $q$ is the radiusvector of a directrix.

A pyramid is a special case of a cone with a polygonal base.

2.1. Conical surface of revolution. It is difficult to single out any structure as a remarkable one. As an illustration, we present the conical shape of the Greek Orthodox Church in Milwaukee, Wisconsin, USA (Figure 2).

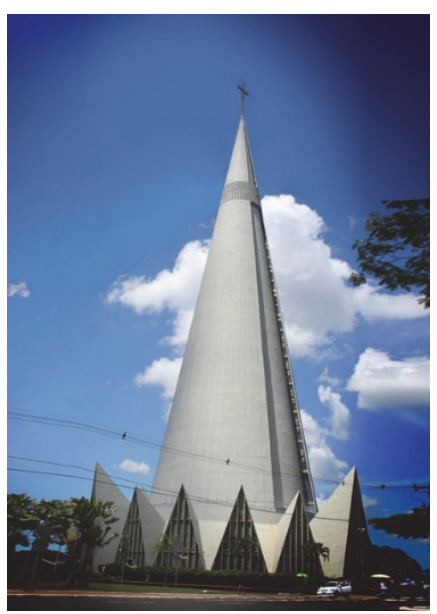

Figure 2. Annunciation Greek Orthodox Church, Milwaukee, Wisconsin, USA

Source: www.arhinovosti.ru

2.2. Inclined circular conical surface. This surface is rarely used by architects, but architect Arthur Erickson used it successfully for the Museum of Glass in Tacoma (USA, 2002).

\section{Cylindrical surfaces}

Both the cylindrical surfaces and the circular conical surfaces are used in the architecture and building since ancient times. Often this is the only possible form for some building structures: pipelines, underground utilities, towers and so on. Cylindrical forms of structures were especially popular from the beginning of the 20th century. This is the architectural Deco Style. However, cylinders find their place in modern life. Conventionally, cylindrical structures can be divided into structures with vertical, horizontal, and inclined axes relatively to the earth's surface.

A cylindrical surface is given by a vector equation

$$
r(s, \lambda)=\rho(s)+\lambda e,
$$

where $\rho(s)$ is the radius-vector of a director curve; $e$ is a unit vector coinciding with the axial direction of the cylinder.

3.1. Cylindrical surface of revolution. In Figure 3, the house-workshop of the architect K.S. Melnikov is presented. This is the one-apartment residential house, 
the world famous monument of Soviet avant-garde in architecture. It was built in 1927-1929 in Moscow on the project of the outstanding architect K.S. Melnikov for himself and his family. The architect believed that the round cylindrical form saves construction materials [13]. Structures in the form of the cylindrical surfaces of revolution can be found in any major city of the world.

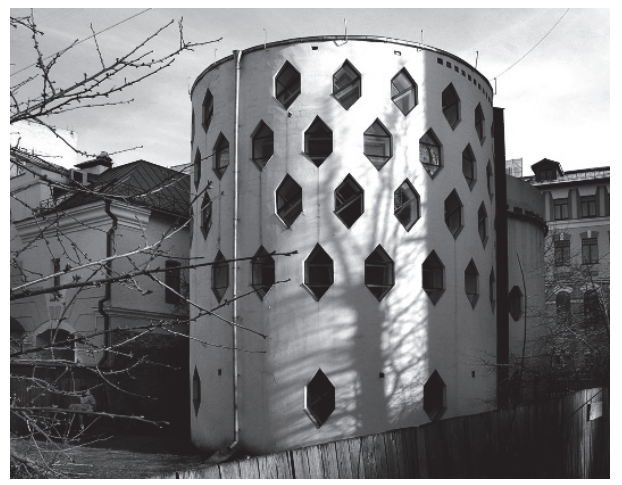

Figure 3. Melnikov's house in the form of two cylinders of different heights, but with the same diameter, Moscow, Russia

3.2. Elliptical cylinder. Even in ancient times, buildings have been built in the form of a vertically placed elliptical cylinder. Basically, they were stadiums and theaters. In support of this, it is possible to point to a stone structure of elliptical shape in plan $(149 \mathrm{~m}$ in length, $124 \mathrm{~m}$ wide and $36 \mathrm{~m}$ high) erected in El Jem, Tunisia, II-III centuries. It is larger than the Luzhniki stadium in Moscow and its three-tiered galleries could accommodate up to 30,000 spectators. At present time, architects also do not forget about the architectural advantages of a vertically placed elliptical cylinder. This is clearly seen on the example of a multi-functional exhibition-and-hotel complex in Moscow on Krasnopresnenskaya nab., 14, developed by the company "Zaha Hadid Architects". Two elliptical in plan high-rise buildings are assumed to build.

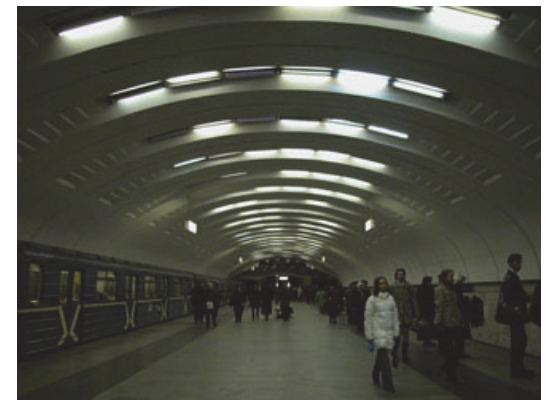

Figure 4. Babushkinskaya metro station, Moscow, Russia, 1978. The illumination of the station is provided by lamps, which are located in the slots of the elliptical arch

In Figure 4, another example of the application of the surface in real structures is shown. Here, the shape of an elliptical cylinder segment with the horizontal axis can be seen in the elliptical vault of the Babushkinskaya underground station in Moscow. The structure of the station is single-vaulted shallow one at a low depth of $10 \mathrm{~m}$. The station was built of precast concrete with the thrust of the vault transmitted to the preconstructed "walls in the ground." V.I. Klokov and L.N. Popov are the authors of the architectural decoration of Babushkinskaya.

3.3. Parabolic cylinder. This surface can be seen in parabolic vaults, which can be illustrated by the example of a hangar in Orly near Paris, France, 1916-1924. The famous French engineer E. Freyssinet designed and built a parabolic cylindrical shell to cover the 30-meter span of the plant in Montluçon, France, in 1905. The parabolic vault was used by architects V.S. Andreev and I.G. Taranov in the design of the pavilion 'Mechanization" (Figure 5) in 1939. The pavilion was a giant parabolic vault covering a wide alley. Not all architects reacted positively to the idea of the authors of the project.

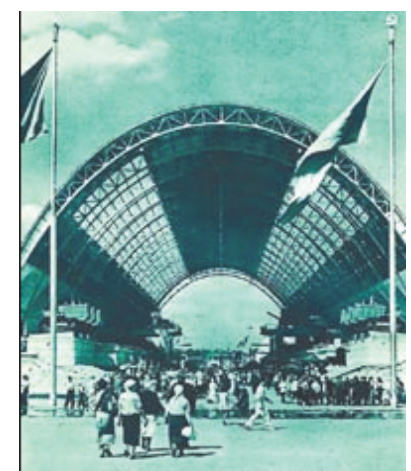

Figure 5. Pavilion "Mechanization", Moscow, Russia

3.4. Sinusoidal cylindrical surface. Sinusoidal cylindrical surfaces are used in folded structures of coatings on the "span", which take up mainly bending internal forces. They are effective for small spans from 12 till $36 \mathrm{~m}$. They are made often of reinforced concrete and fine-mesh wire-fabric reinforced concrete. This surface was used in the design of the bus station roof in Sochi, Russian Federation (Figure 6).

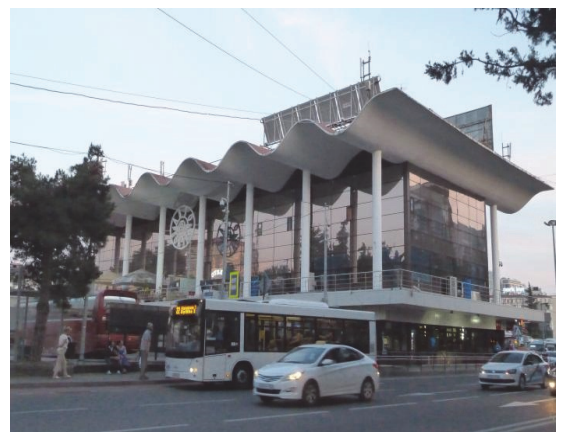

Figure 6. Central Bus Station in Sochi, Russia 
3.5. Cylindrical helical strip. The need to apply this surface is caused by technological requirements for the fences of helical ramps for cars and helical pedestrian staircases (Figure 7).

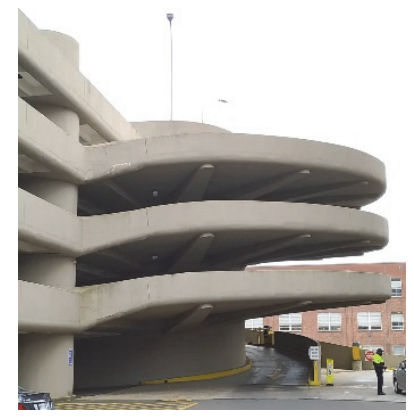

Figure 7. The ramp fence in the form of a helical strip

3.6. Cylindrical-and-conical helical strip. This form of structures has already been encountered in ancient times [8]. The spiral minaret in Samarra, Iraq, was built in 836. It was the largest structure in the Islamic world. From the base to the top, this minaret was made in the form of a cylindrical-and-conical helical strip. This form is used in modern buildings. For example, it can be seen in the form of the facade of the Guggenheim Museum in New York, USA (architect F.L. Wright), or the German Historical Museum in Berlin (architect I.M. Peu, 2001). In Figure 8, it can be seen that the upper part of the Snail tower, a 23-storey residential building, in the Estonian city of Tartu is made in the form of a cylindrical-and-conical helical strip. It is the tallest building in the city since 2008 . The height of the building is almost $90 \mathrm{~m}$.

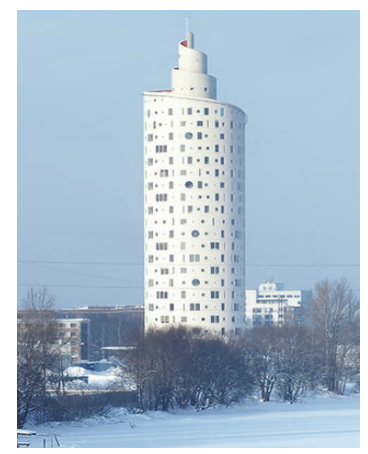

Figure 8. Snail tower, Tartu, Estonia

3.7. Oblique circular cylinder. An oblique circular cylindrical surface is formed by straight generatrixes intersecting a directrix base circle but remaining parallel to the axial direction of the cylinder. This direction forms an acute angle with the basis of the cylinder. A solid volume limited by a cylindrical lateral surface and by two circular bases is called an oblique circular cylinder [1]. A well-known inclined circular tower objects constitute rather great list. However, initially these towers were not planned to be inclined and their shapes, in the strict mathematical sense, are not oblique circular cylindrical surfaces. Now, the design of such structures has become one of the trends of modern high-rise architecture. As an illustration of the application of the considered surface in modern architecture, we can point to the rounded cylindrical cantilever part of the Karolinska medical Institute, Sweden, which became one of the most striking architectural details of this building (Figure 9).

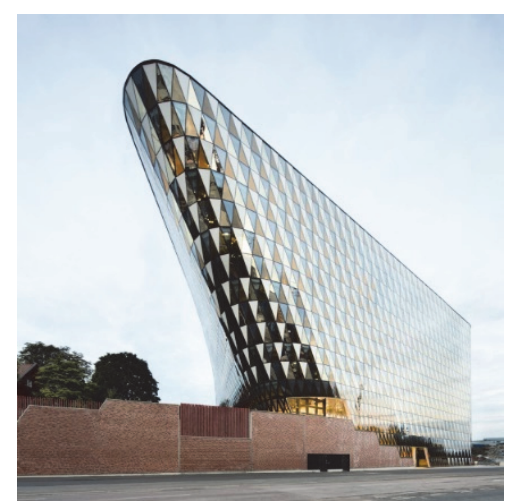

Figure 9. Lecture Hall of Karolinska Medical Institute, Sweden

\section{Ruled surfaces of negative Gaussian curvature}

Classification of ruled surfaces of negative Gaussian curvature containing 36 names is given in a paper [14] and then in the modernized form was reproduced in a monograph [3].

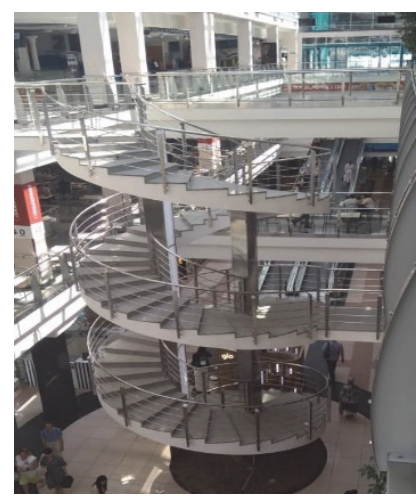

Figure 10. A helical staircase

4.1. Right helicoid. There are 5 types of ruled helical surfaces of negative Gaussian curvature. They can be seen in the structures of machines of various purposes, in the form of special building equipment. Right helicoids can be one of the main elements of the building, for example, ramps of multistoried garages. Complex highway and urban transportation facilities: reinforced concrete and metal scaffold bridges, overpasses, and complex multi-intersection often include helical sections of the artificial structures. 
In the civil and housing construction, helical staircases are widely used, where the right helicoids are taken as their basis (Figure 10). The rectilinear generatrix of a right helicoid crosses the axis of the helicoid at the right angles. Right helicoid is the only ruled minimal surface.

4.2. One-sheet hyperboloid of revolution. This surface is embodied in hundreds of cooling towers. In addition, it has found application in many civil and industrial structures, for example, in the form of a planetarium building in San Louis (USA).

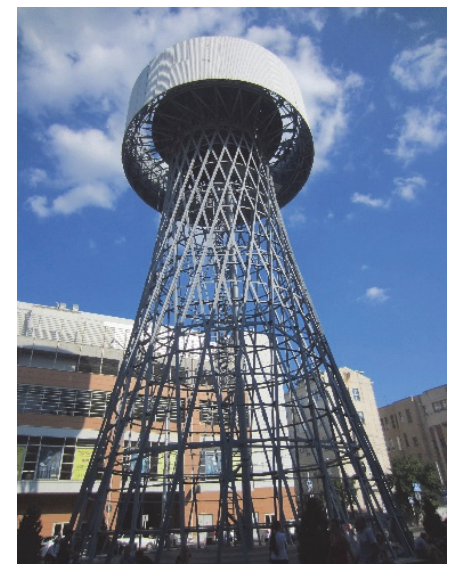

Figure 11. One of the few lattice water towers of V.G. Shukhov in our days, Krasnodar, Russia

The advantages of this surface, formed by two families of straight lines, were well illustrated by V.G. Shukhov in his openwork towers (Figure 11). The idea of V.G. Shukhov to create a supporting part of water towers from lattice structures, the rods of which coincide with the straight generatrixes of a onesheet hyperboloid of revolution, was used in many structures. Structures in the form of a one-sheet hyperboloid of revolution were subsequently used by many great architects including Gaudi, Le Corbusier, and Oscar Niemeyer. The most complete possibilities of these surfaces for architecture are described in a paper [15].

4.3. Conoids. Conoids can be given with the help of parametrical equations:

$$
\begin{gathered}
x=x(u, v)=u \cos v+\alpha f(v), \\
y=y(u, v)=u \sin v+\beta f(v), z=z(v)=\gamma f(v),
\end{gathered}
$$

where $\{\alpha, \beta, \gamma\}$ is the unit vector having the direction of the conoidal axis; $f(v)$ is any function.

Usually, conoidal shells are designed with spans from $12 \mathrm{~m}$ to $24 \mathrm{~m}$ and with the ratio of the span rise equal to 2:1. Calculations show that the span can reach $60 \mathrm{~m}$. In the former USSR, in countries of Eastern Europe, France and Italy, the conoid shells were widely used in 1950-1960 to cover industrial buildings with a span of up to $60 \mathrm{~m}$. These shells are an ideal form for buildings with cantilever coverings. One can learn more about the application of conoidal shells in building from the work [16] or in the monograph [3]. This ruled surface in the hands of experienced architects becomes an architectural sight and a landmark building of the city or the architect.

4.3.1. Right sinusoidal conoid. This surface was glorified by the famous Spanish architect A. Gaudi. He took it as a basis of a covering of a cheap school for children of builders of a Cathedral in Barcelona, Spain (Figure 12). Some architects call this construction ingenious. Another world-famous Spanish architect S. Calatrava spread the idea of A. Gaudi and used of a sinusoidal conoid for the sculpture "Wave" which was installed in front of the museum in Dallas, USA in 2000 [16].

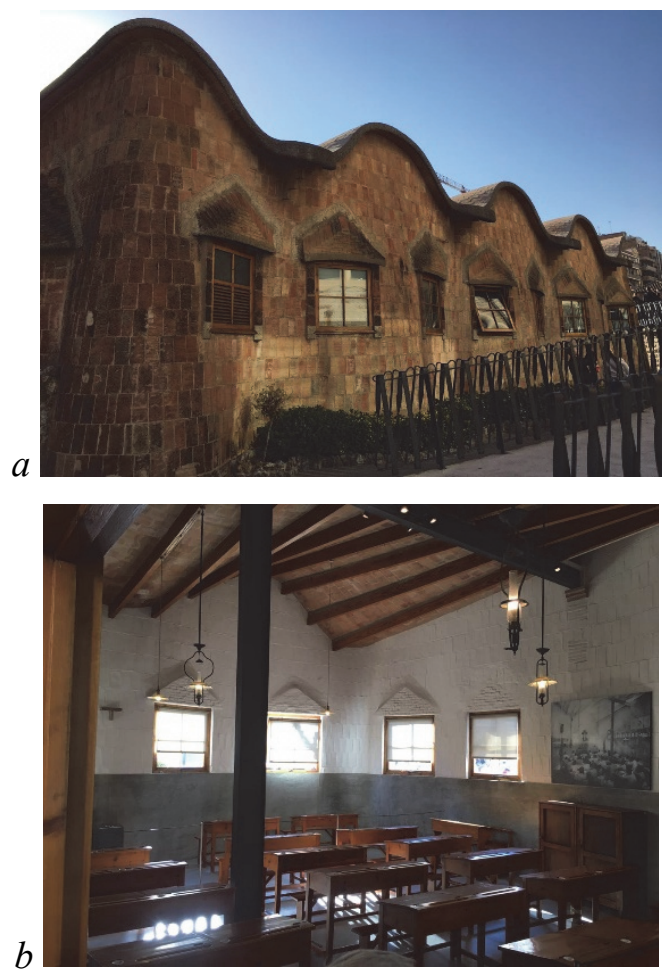

Figure 12. A school with a conoidal roof, Barcelona (Spain): $a$-the walls of the school are made of bricks without facing; $b$ - the metal beams coincide with the straight generatrixes of the conoidal surface

4.3.2. Parabolic conoid. A classic parabolic conoid was selected for reinforced concrete cover of the Summer Theater in Szczecin, Poland, 1998. The 1:100 scale cover model was tested in an aerodynamic wind tunnel at the technical University of Szczecin. The span of the real shell is $60.68 \mathrm{~m}$, its length is $43.3 \mathrm{~m}$, the height is $22.73 \mathrm{~m}$, the thickness is $8.5 \mathrm{~cm}$ [17]. The idea of architects Marcel Breuer, Pier Luigi Nervi, and Bernard Zehrfuss to use a combination of two different parabolic conoids 
and a cylinder between them for the device of a dynamic and graceful console canopy in front of the entrance to the UNESCO building (1953) in Paris was later repeatedly used by other architects.

4.4. Hyperbolic paraboloid. Hyperbolic paraboloid (hypar) is twice-ruled surface of negative Gaussian curvature. Any two rectilinear generatrixes of hypar belonging to different families intersect. Since the early fifties of the $20^{\text {th }}$ century, a burst of interest to structures made in the form of hypar or composed from fragments of hyperbolic paraboloid took place.

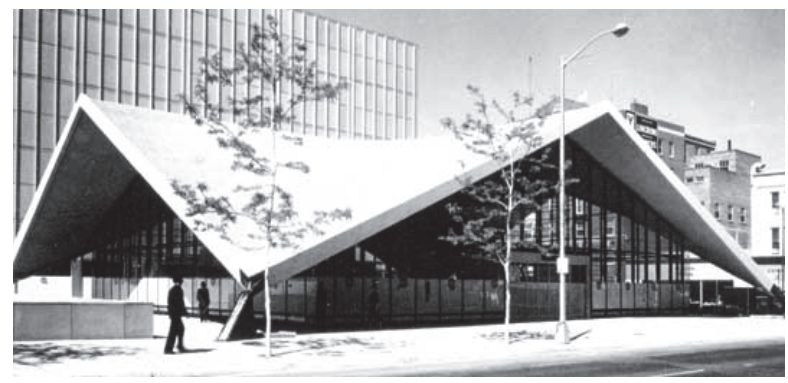

Figure 13. Denver, Colorado, 1959, Courtesy of Princeton University Tedesko Archive [41]

The structures containing several fragments of the hypar aroused the greatest interest and became popular among architects (Figure 13). It is impossible to list all structures in which the form of hyperbolic paraboloid was used, there are hundreds of them. The regularities of the formation of the form of hypar often lead to external similarity, but the plastic capabilities of hypar are so great and visually so various that it is always possible to obtain a structure with individual features. The popularity of the form of hyperbolic paraboloid is evidenced by the fact that Anton Tedesco who is the father of thin-walled shell reinforced concrete structures also participated in the design of the hypar, which, at one time, was considered the world's longest hypar (Denver, Colorado, 1959, courtesy of Princeton University, Tedesko archive).

4.5. Cylindroids. A cylindroid is a ruled surface formed by the movement of rectilinear generatrix along two curvilinear directrixes and in all positions, the generating straight line is parallel to any plane of parallelism. Cylindrical surfaces $(K=0)$ may become cylindroids in certain cases. A cylindroid having one of two directrix curves in the form of a straight line is called a conoid. So, a conoid is a particular case of a cylindroid. Now, five cylindroids are known [1]: cylindroid with two directrix ellipses, cylindroid with two directrix circles lying in mutually perpendicular planes, Frezier's Cylindroid, Ball's Cylindroid, cylindroid with a parabola and a sinusoid lying on the pa- rallel ends. Architectural company "Ishibashi, Tokugawa \& Associates" creates expressive structures in Japan. Located in Tokyo, a team of five architects led by the President of the company Toshihiko Ishibashi has achieved recognition in the architectural world and received several prizes for their work, including the Awards for Merit for the "Chiba City Award for Excellence in Architecture" and "The AICA (Aica Kogyo Company, Limited) Jolypate Contest". This company is trying to introduce elements of modern styles in Japanese architecture. The AICA proposed several types of light corrugated metal roofs in the form of cylindroids (Figure 14) [16].

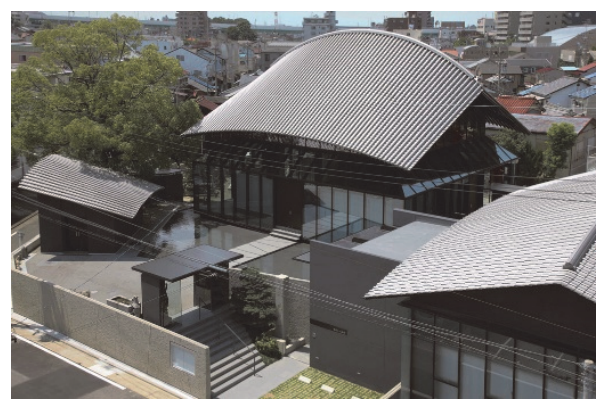

Figure 14. Different types of roofs from corrugated metal in the form of cylindroids, "Ishibashi, Tokugawa \& Associates", Tokyo, Japan

\section{Conclusion}

The study shows that out of the 86 ruled surfaces of zero Gaussian curvature and 46 ruled surfaces of negative Gaussian curvature listed in the encyclopedia [1] only 16 surfaces have been used in architecture and building in the world. These data suggest that geometricians are significantly ahead of the needs of architects and builders, or architects have not yet mastered the entire set of analytical ruled surfaces proposed by geometricians, or architects and engineers consider the most analytical surfaces unsuitable for their creative concepts. They prefer analytically undefined surfaces. Often the shape of surface is designed by architects and geometricians make later its mathematical description. In a number of works related to the design of objects in the form of analytical surfaces, errors in their definition or discrepancies occur [18-20]. The author in their manuscript tried to use the correct definitions of surfaces and the corresponding terms.

For clarity, a classification of analytical surfaces of zero Gaussian curvature is given in Figure 15 and a classification of ruled surfaces of negative Gaussian curvature is given in Figure 16 [3; 14]. The surfaces, found the application in architecture and building, are darkened. 


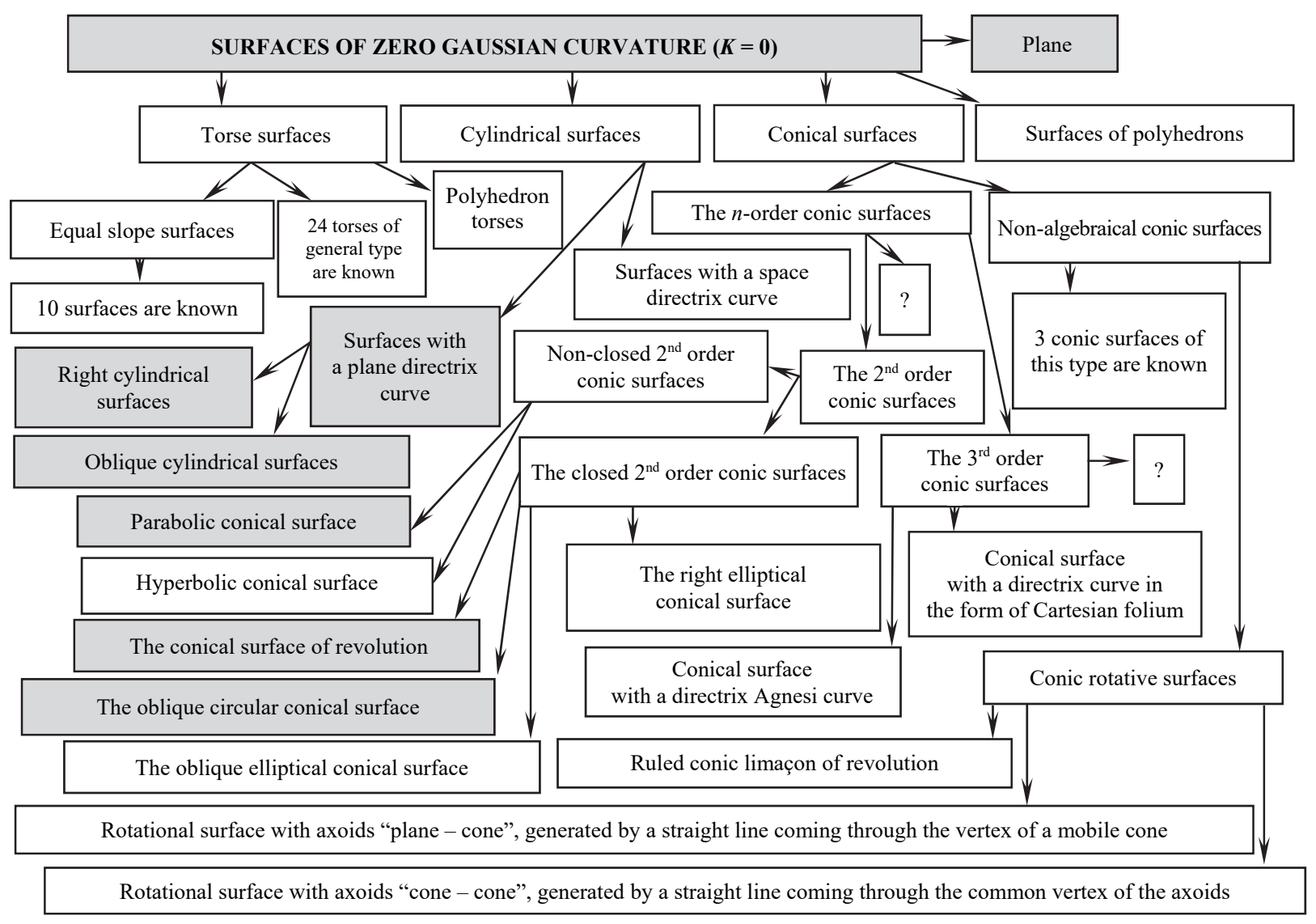

Figure 15. Surfaces of zero Gaussian curvature

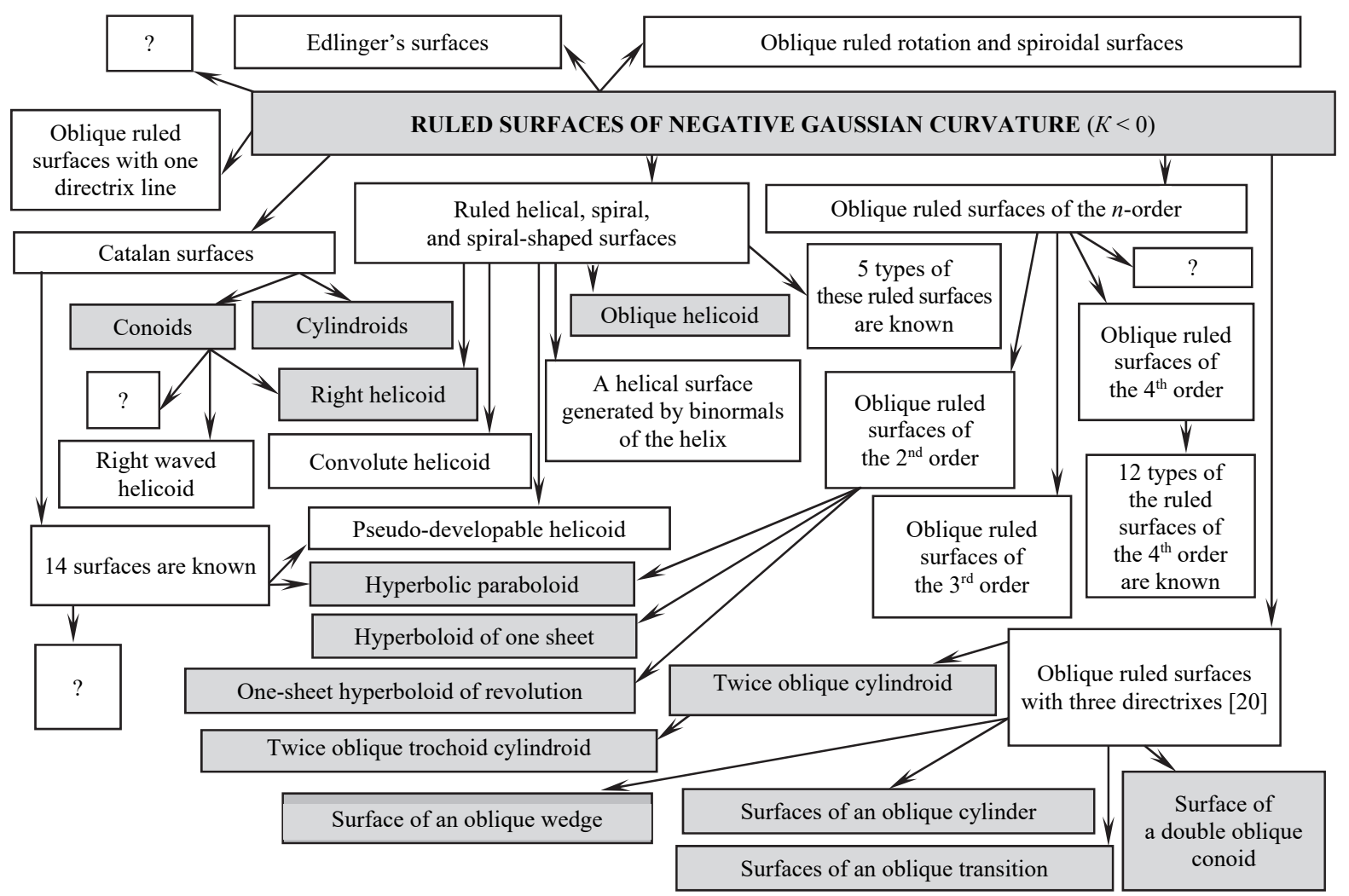

Figure 16. Ruled surfaces of negative Gaussian curvature 
With the advent of variation difference method, finite element method, and other numerical methods, engineers received a powerful tool for the expanded using of thin-walled large-span shells and other types of structures of various shapes.

\section{References}

1. Krivoshapko S.N., Ivanov V.N. (2015). Encyclopaedia of Analytical Surfaces. Switzerland, Springer International Publishing, 752.

2. Grinko E.A. (2018). Classification of analytical surfaces as applied to parametrical architecture and machine building. RUDN Journal of Engineering Researches, 19(4), 438-456. (In Russ.) http://dx.doi.org/10.22363/ 2312-8143-2018-19-4-438-456

3. Krivoshapko S.N., Mamieva I.A. (2018). Analiticheskie poverhnosti $v$ arhitekture zdaniy, konstruktziy i izdeliy [Analytical surfaces in architecture of buildings, structures, and products], Moscow: LIBROCOM Publ., 328. (In Russ.)

4. Podgorniy A.L., Grinko E.A., Solovey N.A. (2013). On research of new surface forms as applied to structures of diverse purpose. RUDN Journal of Engineering Researches, (1), 140-145. http://journals.rudn.ru/engineering-researches/ article/view/4746 (In Russ.)

5. Mamieva I.A., Razin A.D. (2014). Parametrical architecture in Moscow. Architecture and construction of Russia, (6), 25-29. https://elibrary.ru/download/elibrary 21614483_18612954.pdf (In Russ.)

6. Mamieva I.A. (2011). O klassifikacii analiticheskih poverhnostej [On classification of analytical surfaces]. International Scientific-and-Practical Conference "Engineering System-2011", Moscow, 63-65. (In Russ.)

7. Krivoshapko S.N. (1998). Static analysis of shells with developable middle surfaces. Applied Mechanics Reviews, 51(12-1), 731-746.

8. Krasic S. (2012). Geometrijske Površi u Arhitekturi. Gradevinsko-Arhitektonski Fakultet, Univerzitet u Nišu, 238.
9. Lawrence S. (2011). Developable surfaces: their history and application. Nexus Network Journal, 13(3), 701-714.

10. Velimirovic L., Cvetkovic M. (2008). Developable surfaces and their application. Mongeometrija: Proceedings of the $24^{\text {th }}$ International Scientific Conference on Descriptive Geometry, Serbia, September 25-27, 394-403.

11. Krivoshapko S.N. (2019). Perspectives and advantages of tangential developable surfaces in modeling machine-building and building structures. Bulletin of Civil Engineers, 1(72), 20-30.

12. Maryam Ashkan, Yahaya Ahmad. (2012). Significance of conical and polyhedral domes in Persia and surrounding areas: morphology, typologies and geometric characteristics. Nexus Network Journal, 14(2), 275-290. doi: 10.1007/s00004-012-0112-x

13. Denisov A.V., Granit B.A., Levochkin S.N. (2018). About technical condition of structures and soil foundation of the Melnikov's House in Moscow. Industrial and Civil Engineering, (5), 46-53.

14. Krivoshapko S.N. (2006). Classification of ruled surfaces. Structural Mechanics of Engineering Constructions and Buildings, (1), 10-20.

15. Krivoshapko S.N. (2002). Static, vibration, and buckling analyses and applications to one-sheet hyperboloidal shells of revolution. Applied Mechanics Reviews, 55(3), 241-270.

16. Krivoshapko S.N. (2017). The application of conoid and cylindroid in forming of buildings and structures of shell type. Building and Reconstruction, 5(73), 34-44.

17. Paczkowski W., Drozdowicz R., Mielczarek M. (2001). Badania modelowe powloki walcowej w tunelu aerodynamicznym. Inzynieria i Budownictwo, 5(96), 307-309.

18. Mamieva I.A. (2011). Geometrical terminology as applied to umbrella surfaces. Structural Mechanics of Engineering Constructions and Buildings, (2), 78-79. http://journals. rudn.ru/structural-mechanics/article/view/10946 (In Russ.)

19. Krivoshapko S.N. (2017). On errors in terminology on theory of surfaces and geometric modelling. Geometry \& Graphics, 5(2), 32-38.

20. Gheorghiu Ad., Dragomir V. (1978). Geometry of Structural Forms. London, Applied Science Publisher Ltd.

\title{
Влияние геометрических исследований линейчатых поверхностей на создание уникальных сооружений
}

\author{
И.А. Мамиева \\ Российский университет дружбы народов, Российская Федераџия, 117198, Москва, ул. Миклухо-Маклая, 6 \\ mamieva-ia@rudn.ru
}

\section{История статьи:}

Поступила в редакцию: 22 мая 2019 г.

Доработана: 13 июля 2019 г.

Принята к публикации: 27 июля 2019 г.

\section{Аннотация}

Цель исследования, обусловленная ростом интереса к проектированию, расчету и применению архитектурно-строительных конструкций и сооружений в форме разнообразных гладких и составных поверхностей, - проиллюстрировать применение аналитических поверхностей, то есть поверхностей, которые можно задать векторными, параметрическими или явными уравнениями, в параметрической архитектуре. Методы. Параметрическое проектирование, в отличие от других стилей, имеет взаимосвязь с математикой. Эта статья продолжает серию работ автора, посвященных применению аналитических 


\section{Для цитирования}

Mamieva I.A. Influence of the geometrical researches of ruled surfaces on design of unique structures (Влияние геометрических исследований линейчатых поверхностей на создание уникальных сооружений) // Строительная механика инженерных конструкций и сооружений. 2019. Т. 15. № 4. C. 299-307. http://dx.doi.org/10.22363/18155235-2019-15-4-299-307 поверхностей в архитектуре и инженерных конструкциях, изучению влияния исследований по геометрии линейчатых поверхностей на создание уникальных проектов большепролетных оболочечных структур и зданий. В статье приводится перечень известных аналитических поверхностей, каждая из них иллюстрируется фотографией одного реального сооружения, очерченного по описываемой поверхности. Выводы. Выяснилось, что только вырожденные развертывающиеся поверхности, описанные в научной литературе, нашли применение в мире. Для тех, кто интересуется математической стороной проектирования аналитических поверхностей, их компьютерным моделированием или более подробными сведениями о реальных сооружениях в форме рассматриваемых поверхностей, приведена библиография из 20 наименований.

Ключевые слова: параметрическая архитектура; геометрия поверхностей; линейчатые поверхности; формообразование поверхностей; классификация линейчатых поверхностей; гауссова кривизна поверхностей; оболочка; большепролетные оболочечные структуры

\section{Список литературы}

1. Krivoshapko S.N., Ivanov V.N. Encyclopaedia of Analytical Surfaces. Switzerland: Springer International Publishing, 2015. $752 \mathrm{p}$.

2. Гринько Е.A. Классификация аналитических поверхностей применительно к параметрической архитектуре и машиностроению // Вестник Российского университета дружбы народов. Серия: Инженерные исследования. 2018. Т. 19. № 4. С. 438-456. http://dx.doi.org/ 10.22363/2312-8143-2018-19-4-438-456

3. Кривошапко С.Н., Мамиева И.А. Аналитические поверхности в архитектуре зданий, конструкций и изделий: монография. М.: Либроком, 2018. 328 с.

4. Подгорный А.Л., Гринько Е.А., Соловей Н.А. Исследование новых форм поверхностей применительно к конструкциям различного назначения // Вестник Российского университета дружбы народов. Серия: Инженерные исследования. 2013. № 1. С. 140-145. http://journals.rudn.ru/ engineering-researches/article/view/4746

5. Мамиева И.А., Разин А.Д. Параметрическая архитектура в Москве // Архитектура и строительство России. 2014. № 6. С. 24-29. https://elibrary.ru/download/ elibrary_21614483_18612954.pdf

7. Мамиева И.А. О классификации аналитических поверхностей // Инженерные системы - 2011: тезисы докладов Международной научно-практической конференции. М., 2011. С. 63-65.

7. Krivoshapko S.N. Static analysis of shells with developable middle surfaces // Applied Mechanics Reviews. 1998. Vol. 51. No. 12. Part 1. Pp. 731-746.

8. Krasic S. Geometrijske Površi u Arhitekturi. Gradevinsko-arhitektonski fakultet Univerzitet u Nišu, 2012. 238 p.

9. Lawrence $S$. Developable surfaces: their history and application // Nexus Network Journal. 2011. Vol. 13. No. 3. Pp. 701-714.

10. Velimirovic L., Cvetkovic M. Developable surfaces and their application // Mongeometrija: Proceedings of the $24^{\text {th }}$ International Scientific Conference on Descriptive Geometry, Serbia, September 25-27, 2008. Pp. 394-403.
11. Кривошапко С.Н. Перспективы и преимущества торсовых поверхностей при моделировании машиностроительных и строительных конструкций // Вестник гражданских инженеров. 2019. № 1 (72). С. 20-30.

12. Maryam Ashkan, Yahaya Ahmad. Significance of conical and polyhedral domes in Persia and surrounding areas: morphology, typologies and geometric characteristics // Nexus Network Journal. 2012. Vol. 14. No. 2. Pp. 275-290. doi: 10.1007/s00004-012-0112-x

13. Денисов А.В., Гранит Б.А., Левочкин С.Н. О техническом состоянии конструкций и грунтов памятника архитектуры «Дом Мельникова» в Москве // Промышленное и гражданское строительство. 2018. № 5. C. 46-53.

14. Кривошапко С.Н. Классификация линейчатых поверхностей // Строительная механика инженерных конструкций и сооружений. 2006. № 1. С. 10-20.

15. Krivoshapko S.N. Static, vibration, and buckling analyses and applications to one-sheet hyperboloidal shells of revolution // Applied Mechanics Reviews. 2002. Vol. 55. No. 3. Pp. 241-270.

16. Кривошапко С.Н. Применение коноида и цилиндроида при формообразовании зданий и сооружений оболочечного типа // Строительство и реконструкция. 2017. № 5 (73). С. 34-44.

17. Paczkowski W., Drozdowicz R., Mielczarek M. Badania modelowe powloki walcowej w tunelu aerodynamicznym // Inzynieria i Budownictwo. 2001. No. 5(96). Pp. 307-309.

18. Мамиева И.А. Геометрическая терминология применительно к зонтичным поверхностям // Строительная механика инженерных конструкций и сооружений. 2011. № 2. C. 78-79. URL: http://journals.rudn.ru/ structural-mechanics/article/view/10946

19. Кривошапко С.Н. К вопросу об ошибках в терминологии по теории поверхностей и геометрического моделирования // Геометрия и графика. 2017. Т. 5. № 2. C. $32-38$.

20. Gheorghiu Ad., Dragomir V. Geometry of Structural Forms. London: Applied Science Publisher Ltd., 1978.

Мамиева Ираида Ахсарбеговна, ассистент, департамент строительства, Инженерная академия. 